Open Access

\title{
Entrepreneurial intent among prospective graduates of higher education institution: an exploratory investigation in Kafa, Sheka, and Bench-Maji Zones, SNNPR, Ethiopia
}

Edomgenet Hiba Issa ${ }^{1 *}$ (D) and Zerebruk Zewdu Tesfaye ${ }^{2}$

*Correspondence: edomzorander@ gmail.com

'Mizan-Tepi University, Mizan-Aman City, Ethiopia

Full list of author information is available at the end of the article

\begin{abstract}
The purpose of this paper is to present results of an exploratory study conducted on entrepreneurial intent among graduating class students of higher education institutions in Kafa, Sheka, and Bench-Maji Zones, Southern Nation Nationalities Peoples' Region (SNNPR), Ethiopia. The research design of the study was a cross-sectional survey design where relevant data were collected through questionnaires from a sample of 347 University and Technical and Vocational Education and Training (TVET) College graduating class students. The data were analyzed using both descriptive statistics (bar graph and pie chart) and inferential statistics (chi-square goodness-of-fit test, independent samples $t$ test, and oneway between-group analysis of variance). The study found out that among prospective graduates of higher education institutions in the study area, only $45.4-50.6 \%$ had low, 24$33.7 \%$ had moderate, and $18-25 \%$ had a high level of entrepreneurial intent. The study also showed that the level of higher education, prior experience of self-employment, and the chance of taking extracurricular entrepreneurship courses were the three demographic and other distal variables that explained the difference in entrepreneurial intent among the study population. The study, however, showed gender, the chance of taking entrepreneurship courses as part of curriculum, college, department, parent's occupation, and level of education had no statistically significant association with entrepreneurial intent of the study population. The study is expected to hold relevant inputs to politicians and national policy-makers, the Ministry of Science and Higher Education, entrepreneurial intent researchers, and model developers.

Keywords: Entrepreneurial intent, Demographic variables, Gender, University, TVET College, Department, Entrepreneurship education, Prior experience in self-employment, and parents' occupation and education
\end{abstract}

(c) The Author(s). 2020 Open Access This article is licensed under a Creative Commons Attribution 4.0 International License, which permits use, sharing, adaptation, distribution and reproduction in any medium or format, as long as you give appropriate credit to the original author(s) and the source, provide a link to the Creative Commons licence, and indicate if changes were made. The images or other third party material in this article are included in the article's Creative Commons licence, unless indicated otherwise in a credit line to the material. If material is not included in the article's Creative Commons licence and your intended use is not permitted by statutory regulation or exceeds the permitted use, you will need to obtain permission directly from the copyright holder. To view a copy of this licence, visit http://creativecommons.org/licenses/by/4.0/. 


\section{Introduction}

Ethiopia is the second-most populous country in African. Its population is estimated at 104 million of which the youth population (age 15 to 29) is estimated to be more than 29 million (USAID, 2017). The USAID (2017) report also indicated that Ethiopia has a relatively higher rate of youth unemployment estimated at $27 \%$.

The general unemployed youth population in Ethiopia may constitute different segments of youths characterized by various demographic features. One of these segments embodies higher education graduates. As compared to the total youth unemployment rate in the country, the unemployment rate of higher education graduates appears to be by far greater. For instance, the average current self-estimated graduate unemployment rate for universities is around 40\% (Delivery Associates Ltd., 2017).

Various studies have documented that youth unemployment has been a cause for various socio-economic and political problems. Some of these studies suggest that youth unemployment is one of the underlying causes of crime and delinquency apparent in the urban areas of Ethiopia (i.e., Astatike, 2003; Fanchu, 2017; Fila, Mansingh, \& Legesse, 2016; Kassaye, Sherief, Fissehaye, \& Teklu, 1999).

Some studies have revealed the fact that the illegal and deadly migration of Ethiopians venture towards Europe and Arabian Gulf countries has also been the result of youth unemployment conditions in the nation (De, 2010; Ternandez, 2011).

The condition of youth unemployment has also been acclaimed to be one of the basic forces which fueled the violent public protests the country has experiences now and then (Astatike, 2003; Wubie, 2012).

In the last 10 years, efforts of different forms at different levels have been made to mitigate youth unemployment in Ethiopia. One of these efforts is encouraging entrepreneurialism. The government of Ethiopia has been trying to encourage entrepreneurialism through different strategies.

Some of these strategies were incorporating the issue of entrepreneurship in various policy frameworks; providing loans and working place for youths organized in small scale and micro enterprises; promoting individual and societal significance of entrepreneurship; and disseminating scientific knowledge of entrepreneurship and building entrepreneurial skills of citizens via curricular and extra-curricular entrepreneurship course works and short-term trainings (Astatike, 2003; Broussar \& Tekleselassie, 2012; International Labour Organization, 2017; Ministry of Education (MoE), 2007).

Despite the government's effort to mitigate youth unemployment through promoting entrepreneurship, the unemployment rate of college and university graduates is yet increasing (Broussar \& Tekleselassie, 2012; Denu, Tekeste, \& Deijl, 2005).

Evidence shows that entrepreneurial behavior is one of the factors closely associated with unemployment conditions (Audretsch, Carree, \& Thurik, 2001; Bergmann \& Sternberg, 2007; Bosma \& Levie, 2010; Mukorera \& Mahadea, 2014; Tewolde, Feleke, Mamo, Hayat, \& Siyom, 2016; Thurik \& Wennekers, 2004). Relatedly, incognizant of the role of entrepreneurial behavior in the economy on the one hand and the role of entrepreneurial intent in predicting entrepreneurial behavior, on the other hand, studies have called for further research on entrepreneurial intention (Ajzen, 1991; Gartner, Shaver, Gatewood, \& Katz, 1994; Krueger Jr \& Day, 2010; Schlaegel \& Koenig, 2014). 
Considering this study as a response to the calls for further research on entrepreneurial intention, additional exploration was made to locate influential works on the subject matter. Surprisingly, much of the literature on entrepreneurial intention was found closely associated with one man and his seminal work-Ick Ajzen and his theory of planned behavior.

Ick Ajzen is the man who proposed a theory of planned behavior in 1991. In his theory, Ajzen suggests that engagement in entrepreneurial activity is a planned behavior, and entrepreneurial intent is the best indicator of an individual's tendency to become an entrepreneur (Ajzen, 1991). Since then, entrepreneurial intent has been one of the most common research agendas in social and behavioral studies across the world.

In the past three decades, researchers have been exploring the different aspects of entrepreneurial intent. Some were interested in a comparative study of the level of entrepreneurial intent between different population groups (Basu \& Virick, 2007; Castellano, Maalaoui, Safraou, \& Reymond, 2014; De Pillis \& Reardon, 2007; DíazCasero, Ferreira, Mogollón, \& Raposo, 2012; Es \& Urbano, 2005 ; Jenkins \& Johnson, 1997; Liñán \& Chen, 2006). Some researchers were interested in developing a reliable measurement scale for entrepreneurial intent (Ozgul \& Kunday, 2015; Thompson, 2009; Valliere, 2014, 2015; Wang, Lin, \& Jiang, 2013). Whereas the vast majority, however, have been interested in studying determinants of entrepreneurial intent (Altinay, Madanoglu, Daniele, \& Lashley, 2012; Devonish, Alleyne, Charles-Soverall, Marshall, \& Pounder, 2010; Fayolle, Gailly, \& Lassas-Clerc, 2006; Gelard, 2012; Lüthje \& Franke, 2003; Meek, Pacheco, \& York, 2010).

A review of related literature indicated that entrepreneurial intent researchers in Ethiopia have been interested in two subject matters. The first subject matter was determining the level of entrepreneurial intent among different study groups. Studies particularly conducted on higher education students suggest that graduates have a lower tendency to engage in entrepreneurial activities soon after graduation (Atnafu, 2016; Binagde, 2014; Megibaru, 2015; Negash \& Amentie, 2013; Tesfaye, 2011). The second subject matter was identifying predictors of entrepreneurial intent. In this regard, studies revealed that determinants of entrepreneurial intent among higher education graduates are socio-cultural factors, economic factors, perceived reliability and feasibility, perceived behavioral control, perceived role expectation, and some demographic factors (Admasie, Kassahun, \& Wodajo, 2018; Alemu \& Ashagre, 2016; Atnafu, 2016; Binagde, 2014; Leta \& Waktole, 2017; Negash \& Amentie, 2013; Tegegn, Paulos, \& Desalegn, 2016; Thuo, Abo, \& Toma, 2016).

From the review of entrepreneurial intent studies conducted so far in Ethiopia, it is evident that most of these studies were conducted in limited demographic and institutional contexts. In fact, most entrepreneurial intent researches were conducted in towns near the capital city and other big towns and cities where there were well established higher education institutions. Entrepreneurial intent of students in emerging towns far from the capital city where the development of higher education institutions is at early stages is yet under-explored if not never explored.

This is a regrettable fact for at least two reasons. First, the lack/inadequacy of entrepreneurial intent research in areas other than the capital city, other big towns, and cities characterized by well-developed higher education institutions creates a greater knowledge gap in the subject matter. Second, such a knowledge gap in of itself is amongst the 
potential obstacles to the efficiency and effectiveness of the national endeavor carried out to alleviate youth unemployment through promoting entrepreneurialism.

Above and beyond, Ethiopia is a country where the majority of the youth population lives in rural areas and emerging towns with the least developed higher education institutions. It seems it is a matter of necessity to scientifically investigate the entrepreneurial intent of students in such contexts so long as the nation strives to minimize youth unemployment through promoting entrepreneurialism. It is even a matter of urgency to study the entrepreneurial intent of students in such contexts, given the fact that one of the underlying factors for the violent protest that has been observed in the south-western Ethiopia in particular and in Ethiopia in general was youth unemployment.

The purpose of this paper is, therefore, to present results of an exploratory study conducted on entrepreneurial intent of higher education graduates in emerging towns far from the capital where higher education institutions were not well established. In exact terms, this paper aims to present findings of a research conducted on higher education institution graduates in Kafa, Sheka, and Bench-Maji Zones, SNNPR, Ethiopia.

This article addresses two specific objectives. The first one is to determine the level of entrepreneurial intention of the study population. The second one is to identify demographic and other distal variables that might justify the difference in entrepreneurial intent among the study population.

\section{Research on entrepreneurial intent}

Entrepreneurial intent has been defined by different scholars across the world in many ways. Tkachev and Kolvereid (1999), for instance, defines entrepreneurial intent as one's willingness to becoming self-employed. Whereas, Choo and Wong (2006), define it as the search for information that can be used to help fulfill the goal of venture creation. (Pihie, Bagheri, \& Sani, 2009), on the other hand, describes entrepreneurial intent as an attitude that influences entrepreneurial behavior. More generally, entrepreneurial intentions can be defined as a conscious awareness and conviction by an individual that sets up a new business venture and plans to do so in the future (Bird, 1988; Thompson, 2009).

Having clarity on the definition of entrepreneurial intent, related studies were reviewed and guided by two major objectives. One objective was to grasp the variability of the level of entrepreneurial intent among different study groups throughout Ethiopia. The other objective was to gain a holistic picture of demographic and other distal variables whereon entrepreneurial intent significantly varies both at national and international contexts.

From the review of studies that tried to determine the level of entrepreneurial intent across population groups in Ethiopia, it can be assumed that graduates of higher education institutions manifest a lesser level of entrepreneurial intent. For instance, Atnafu (2016), observed that 77\% of students at Dire Dawa University have no intention to engage in entrepreneurial activities. In a study, Megibaru (2015), it is documented that $56 \%$ of Gonder University students have no entrepreneurial intent. Many other studies have also reported lower levels of entrepreneurial intent among students of higher 
education institutions (Binagde, 2014; Megibaru, 2015; Mulugeta Atnafu, 2016; Negash \& Amentie, 2013).

Studies conducted both at national and international contexts were also reviewed in an intention to gain a comprehensive picture of demographic and other distal variables that may have a significant effect on an individual's entrepreneurial intent.

Plenty of studies have documented a statistically significant association between entrepreneurial intent and demographic variables such as age, gender, ethnicity, religion, academic status, prior experience, and income (Adem, 2008; Chaudhary, 2017; Daim, Dabic, \& Bayraktaroglu, 2016; Fatoki, 2014; Kautonen, Tornikoski, \& Kibler, 2011; Nguyen, 2018; Quan, 2012; Tegegn et al., 2016; Tewolde et al., 2016).

Regarding other distal variables underlying entrepreneurial intent, many authors have discussed an array of variables. Some of the most commonly identified were parent's occupation, parents' income, and entrepreneurship education (Adem, 2008; Alsos, Carter, \& Ljunggren, 2011; Binagde, 2014; Chaudhary, 2017; Devonish et al., 2010; Fairlie \& Robb, 2007; Fayolle et al., 2006; McElwee \& Al-Riyami, 2003; Nguyen, 2018; Thuo et al., 2016)

As far as the authors' knowledge is concerned, no documented information about the level of entrepreneurial intent and underlying demographic and other distal variables among the study population has been made available in either local or international academic journals. Thus, this study could be considered as an attempt to fill this knowledge gap.

\section{Theoretical framework}

This study rooted its theoretical orientation into Ajzen's Theory of Planned Behavior (TBA). From the two major works of Ajzen $(1987,1991)$, the basic assumptions of TBA can be simply summarized in the following manner: (a) entrepreneurial behavior is an intentionally planned behavior, (b) entrepreneurial intent is the single best predictor of entrepreneurial behavior, (c) Attitude towards the act, subjective norms, and perceived desirability predict entrepreneurial intention, (d) demographic and other distal variables have an indirect effect on entrepreneurial intention.

In this study, the theory of planned behavior had two major purposes. The first one was to recognize entrepreneurial behavior as a planned behavior best predicted by intention and develop a scale to measure the entrepreneurial intent of the study participants. The second one was to recognize the effect of demographic and other distal variables on entrepreneurial intent (though it is in direct) and use those variables to explore the variability of entrepreneurial intent in the study population.

The demographic and other distal variables so far considered relevant to this study were gender, level of higher education, college, department, enrolment in curricular and extra-curricular entrepreneurship education, prior experience of self-employment, and parents' occupation and education.

\section{Methods}

\section{Study design}

This study employed a cross-sectional survey design. The relevant information was collected through self-administered structured questionnaires from 15 March to 21 May 2017. 


\section{Study area and population}

In the Federal Democratic Republic of Ethiopia, there are 9 regional states and two federal cities. Southern Nations, Nationalities, and Peoples' Region (SNNPR) is one of the 9 regional states in Ethiopia.

In SNNPR, there are 14 administrative zones. The study was conducted in three zones of SNNPR-Bench-Maji, Kefa, and Sheka Zones. These zones are located in the Southwestern part of Ethiopia.

The study population was prospective graduates from TVET Colleges and a University. At the time of data collection, the total number of prospective graduates in TVET Colleges and a University considered for this study was 1920. Four hundred fifty were from TVET Colleges and 1470 from University.

\section{Sampling \\ Inclusion and exclusion}

By definition, higher education institution constitutes: independently established TVET College, University, Teachers Training College, Health Science Colleges, and Agriculture College (The Federal Democratic Republic of Ethiopia, 2014). This study, however, included only two of them-TVET college and university. While excluding Teachers Training College, Health Science Colleges, and Agriculture College. The very reason for exclusion was those colleges and their programs were available in different forms under the University considered for inclusion in this study.

\section{Sample size determination}

The sample size was determined using Cochran's formula for calculating a sample for proportions, taking the level of significance at 95\%, $(\alpha=1.96)$, margin of error $5 \%$, and proportion (0.5). The initial sample size estimated was 392. But since the population size was small, the initial sample size was later slightly reduced to 325 using finite population correction for proportions formula as suggested by Cochran (Israel, 1992).

On top of that, as a precaution to minimize the non-response rate, a decision was also made to increase the corrected sample size by one percent which finally made the sample size to be 357. Furthermore, to ensure the representativeness of the findings of this study, the proportionate sample size was also determined for each stratum considered for sampling.

\section{Sampling technique and procedure}

Multistage stratified random sampling technique was employed to capture a representative number of samples from each TVET college and the university.

Stage I: selecting higher education institutions (TVET colleges and university) Stage one of the sampling processes involved first stratifying the study population by type of higher educational institution which was TVET college and university. During the period of data collection, there was only one University (Mizan-Tepi University ${ }^{1}$ )

${ }^{1}$ Readers are advised to note that Bonga University is also one of the two universities located in the study area. But never considered for this study for the reason that the institution was established recently in 2016 and had no graduating class students during the period of data collection-2017. 
and three TVET Colleges (Aman, Bonga, and Tepi TVET Colleges) with graduating class students.

The second step under this stage was selecting University and TVET Colleges. Mizan-Tepi University, by default, was made part of this study for it was the only university hosting graduating class students in the study area. When it comes to TVET Colleges, Bonga and Aman TVET Colleges were randomly selected out of the three TVET Colleges.

Stage II: selecting departments from higher education institutions chosen at stage I For Mizan-Tepi University, this stage involved proportionate random sampling of 15 departments out of the total 35 departments available under 7 colleges. Regarding TVET colleges, all departments common to both Bonga and Aman TVET colleges were considered for sampling. The departments common to both TVET colleges by the time of data collection were 6 .

Stage III: selecting respondents Finally, at this stage, students' attendance list from each department selected at stage II has been collected to make a sampling frame. Then, a random number generator computer program was used to select those respondents who filled out the questionnaires.

\section{Data collection procedures}

It seemed, the process and procedures of data collection of this study would be well described if presented step-wise. It is, thus, described as follows:

\section{Step 1: questionnaire development}

This stage involved reviewing relevant literature, designing a questionnaire in the English language, and translating the English version of the questionnaire into a local language (Amharic language).

\section{Step 2: securing official approval for data collection}

Managing bodies of higher education institutions considered for this study (except Mizan-Tepi University) were officially requested for their approval to collect data from their pupil. The letter of request for approval consisted of information about the title, purpose, objectives, and significance of the study along with ethical conditions regarding the use of the data. Fortunately, the authors had received approval with no delay or complications.

\section{Step 3: training data collectors}

Three data collectors were trained about how to effectively collect data via questionnaire, potential practical challenges that could be faced during data collection on the field, and plausible solutions.

\section{Step 4: actual data collection}

This stage involved the following sequential activities. First, identification of potential respondents following the sampling frame. Second, identification of actual respondents 
(individuals who were willing to fill out the questionnaire). Third, distribution of a selfadministered questionnaire for actual respondents and provision of assistance for the respondents if and whenever needed. Fourth, collection of the filled-out questionnaires from the hand of the respondents and submission to the researchers.

\section{Measure}

\section{Entrepreneurial intent measurement scale and reliability test}

This study adopted an individual entrepreneurial intent measurement scale developed by Thompson (2009). Thompson's scale Cronbach alpha coefficient proved to be 89 . Thus, the scale was assumed to have an acceptable level of internal reliability.

The scale's unidimensionality was assessed using confirmatory factor analysis. This produced a single component with the goodness of fit, adjusted goodness of fit, normed fit, and relative fit indices each well above .90 , thereby indicating adequate model fit. The scale was tested across three different population groups to examine its generalizability. The test result shows that the scale was reliable and unidimensional for each sample groups (Thompson, 2009)

The scale was also tested and retested across four points of time to examine the same-sample stability. The test and retest scale means were not significantly different and their Pearson product-moment correlation coefficients of reliability were above 0.87 (Thompson, 2009)

To test the scale's Cross-National and Cross-Population Stability and Nonresponse Bias, it was incorporated in an online instrument sent to an international convenience sample of 1697 in two waves. From the tests, the scale came out to be cross-cultural applicability (Thompson, 2009).

Thompson (2009) developed a unidimensional, content-valid, internally reliable, criterion-valid, and cross-culturally invariant metric of entrepreneurial intent. So, this study adapted Thompson's entrepreneurial intent measurement scale with slight modification and tested for its reliability before further analysis ${ }^{2}$.

The reliability test of a six-item scale showed a Cronbach's Alpha coefficient of 0.641. But, if items (item 1.2r and item 1.5r) were deleted, the Cronbach alpha coefficient would become 0.667 . Thus, in an intention to maximize the reliability of the scale the researchers decided to eliminate the two question items (1.2r and item 1.5r).

According to McMillan and Schumacher (2006), a good rule of thumb is that the reliability needs to be 0.7 or higher though. It is worthwhile to include variables of which the reliability values are less than 0.7. McMillan and Schumacher (2006) suggested that reliability values are highly dependent on the number of items, so alpha values of 0.5 and 0.66 are acceptable for most research purposes. Therefore, it was decided to retain the remaining four other items for further analysis.

\section{Analysis}

This study made use of both descriptive and inferential data analysis procedures. Bar graph and Pie chart were used for descriptive statistical analysis and presentation. Chisquare goodness of fit test, independent samples $t$ test, and one-way between-group analysis of variance (ANOVA) were used for inferential analysis.

${ }^{2}$ See Additional file 1 and 2 


\section{Reliability and validity}

No matter how long a research took or how much money invested on, or whoever conducted it, it is conventional wisdom that it would be useful if only achieved certain quality standards. In the literature on research methods, there are two basic standards of quality for any research. These criteria of quality are reliability and validity. Kimberlin and Winterstein (2008) state that the evidence of validity and reliability are prerequisites to assure the integrity and quality of a measurement instrument. Thus, as an attempt to assure the integrity and quality of a measurement instrument (entrepreneurial intent measurement scale), the reliability and validity issues of this study are discussed in the following two sub-headings.

\section{Reliability}

Reliability refers to the consistency, precision, replicability, and trustworthiness of a research finding (Chakrabartty, 2013). Reliability has two types: stability and internal consistency (Mohajan, 2017). Reliability as stability is defined as the ability of a measure to remain the same across time (Mohajan, 2017). One of the mechanisms used to increase the stability of a measurement instrument is to adopt a pre-established instrument whose psychometric properties has been tested across different population over time (Streiner, Norman, \& Cairney, 2015). Accordingly, this study adopted an entrepreneurial intent measurement scale developed by Thompson (2009). The scale was an established scale whose validity and reliability were tested across different populations and has been proved valid and reliable. For further information, read the "Measure" section of this paper.

Reliability as an internal consistency, on the other hand, is defined as the degree to which different items that represent the same concept provide the same result (Mohajan, 2017). One of the methods used to evaluate the internal consistency of a measurement instrument is a Cronbach alpha test (Cortina, 1993). Thus, a Cronbach alpha test was run to test the inter-item consistency of the entrepreneurial intent measurement scale of this study. The Cronbach alpha coefficient was 0.667. The coefficient was deemed acceptable upon the recommendation of McMillan and Schumacher (2006). For more information, read the "Measure" section part of this paper and also refer to Additional file 2.

Besides, upon the recommendation of Nunnally and Bernstein (1978), this study had also tried to improve the reliability of the findings by writing question items with clarity, making instructions easily understandable, and training data collectors, and making the rules for scoring as explicit as possible.

\section{Validity}

Validity indicates the extent to which a measurement scale measures what is intended to measure (Thatcher, 2010). There are two essential parts of validity: internal validity and external validity (Mohajan, 2017). Internal validity is defined as the extent to which results are legitimate considering the sampling, data collection, and analysis methods and procedures. It represents the credibility of findings (Mohajan, 2017). Researchers can maximize the internal validity of their findings through strategies such as members check, peer-review, reflexivity, saturation, 
prolonged contact, and triangulation (Mohajan, 2017). Among these strategies, the authors made use of peer-review and reflexivity to increase the internal validity of the entrepreneurial intent measurement scale. Especially, the comments of three peer-reviewers and the constant reflection of the authors were of great importance during the research stage where the English version of the questionnaire was translated into a local language (Amharic language).

External validity, on the other hand, indicates the extent to which findings of a study are transferable to other study populations (Last, Harris, Thuriaux, \& Spasoff, 2001). Researchers can increase external validity through achieving representation of the population, using heterogeneous groups, using non-reactive measures, and using precise descriptions to allow for study replication (Mohajan, 2017). Among these strategies, this study had employed three of them. First, a stratified-cluster random sampling strategy was used to represent the study population naturally grouped in terms of the level of higher institution (university and TVET college), colleges, departments, and localities (Mizan-Aman, Bonga, and Tepi Towns). Second, the study was conducted on a study population with heterogeneous groups. The heterogeneity of the groups in this study was maintained by selecting participants from different levels of higher institution, college, department, and localities. Three, the authors have tried their best to explicitly and precisely describe the sampling, data collection, and analysis methods and procedures so that other researchers could easily replicate this study.

\section{Results}

Basic information of the research participants

In this study, a total number of 347 respondents had participated. Out of these respondents, $71.2 \%$ and $28.8 \%$ were from university and TVET colleges respectively. In terms of gender, $68.3 \%$ were male and $31.7 \%$ were female.

To ensure the representativeness of the research finding, through the sampling procedures, the study has considered all the available colleges as sampling units. Accordingly, the proportionate sample constituted 13.0\% Social Sciences and Humanities, 4.0\% Business and Economics, 14.4\% Agriculture and Natural Resource, 4.0\% Health Science, 21.0\% Engineering and Technology, 4.3\% Informatics, 10.4\% Natural and Computational Science, 16.1\% Aman TVET, and 12.7\% Bonga TVET Colleges.

\section{Level of entrepreneurial intent}

The entrepreneurial intent of the study population was primarily measured through a 4-point Likert scale as a continuous variable. But only for analysis in this section which involved categorizing and ordering, the total Likert scale score was collapsed into a three-category (low, moderate, and high) ordinal variable ${ }^{3}$.

\footnotetext{
${ }^{3}$ The Entrepreneurial Intent Likert scale score was collapsed into a three-category ordinal variable through visual binning data transformation process in IBMSPSS 22. In the data transformation process, after 347 cases were scanned, those with average scale score $\leq 2.5$ were categorized as 'low,' $2.5-3$ as 'moderate,' and $\geq$ 3 as 'high'
} 
A descriptive analysis of the sample data was run after the entrepreneurial intent scale score had been transformed. The result showed that out of 347 sample respondents: 167 (48.1\%), 103 (29.7\%), and 77 (22.2\%) fall under the category of Low, Moderate, and High level of entrepreneurial intent respectively. Figure 1 presents the percentage distribution of the level of entrepreneurial intent among sample respondents.

A chi-square goodness of fit test (see Table 1) was conducted to determine whether the difference in the proportion among the three categories of entrepreneurial intent was a random occurrence or not. The chi-square test showed that there was a significant difference (chi-square $=37.095, \mathrm{df}=2$, and $p=.000$ ) between the observed and expected number of respondents across the three categories of entrepreneurial intent.

Further analysis was made to estimate how much percentage of the study population would probably have low, moderate, and high levels of entrepreneurial intent. During the population proportion estimation, confidence level $(1-\alpha)$ and confidence coefficient $\left(\mathrm{z}_{\alpha / 2}\right)$ were kept at $95 \%$ and 1.96 , respectively. The estimation indicated that the upper and lower confidence limits for the proportion of population with low, moderate, and high levels of entrepreneurial intent were $\{0.454$, $0.506\},\{0.24,0.33\},\{0.18,0.25\}$, respectively. Thus, with $95 \%$ accuracy, we can conclude that among prospective graduates of higher education institutions in the study area, only $45.4-50.6 \%$ had low, $24-33.7 \%$ had moderate, and $18-25 \%$ had a high level of entrepreneurial intent.

\section{Demographic and other distal variables that may explain difference in entrepreneurial intent}

Entrepreneurial intent scale score was compared across demographic and other distal variables of the study population. Variables considered for the comparison were:

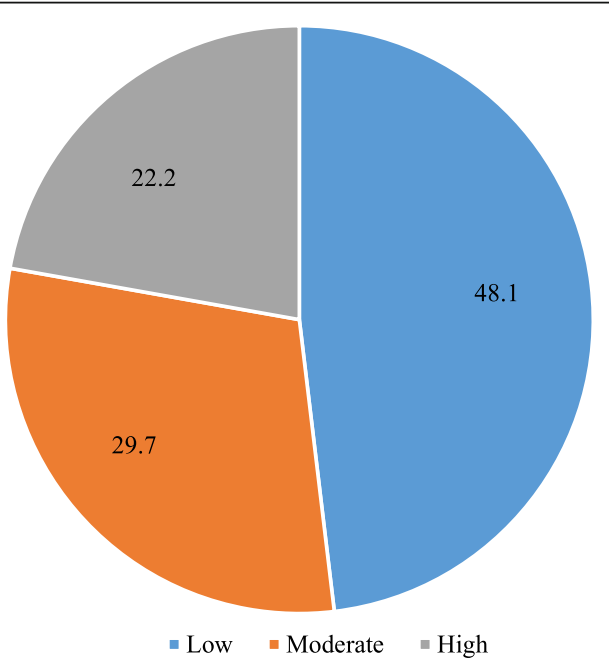

Percentage Distribution of Level of Entrepreneurial Intent among Sample Respondents

- Source: survey data

Fig. 1 Percentage distribution of level of entrepreneurial intent among sample respondents. Source: survey data 
Table 1 Chi-square goodness of fit test result on the level of entrepreneurial intent

\begin{tabular}{|c|c|c|c|c|c|c|}
\hline \multirow{2}{*}{$\begin{array}{l}\text { Entrepreneurial } \\
\text { intent scale } \\
\text { score (binned1) }\end{array}$} & \multicolumn{3}{|l|}{ Descriptive } & \multicolumn{3}{|c|}{ Test statistics } \\
\hline & Observed N & Expected $N$ & Residual & Chi-square & $d f$ & Asymp. sig. \\
\hline Low & 167 & 115.7 & 51.3 & $37.095^{a}$ & 2 & .000 \\
\hline Moderate & 103 & 115.7 & -12.7 & & & \\
\hline High & 77 & 115.7 & -38.7 & & & \\
\hline Total & 347 & & & & & \\
\hline
\end{tabular}

${ }^{\mathrm{a}} 0$ cells $(0.0 \%)$ have expected frequencies less than 5 . The minimum expected cell frequency is 115.7

Source: survey data

level of higher education, gender, the chance of taking curricular and extracurricular entrepreneurship course, college, department, prior experience of selfemployment, parent's occupation, and educational status. Statistical procedures applied for the comparison were independent sample $t$ test and between groups ANOVA.

\section{Independent sample $t$ test results}

An independent sample $t$ test was conducted to test the difference in entrepreneurial intent scale score across variables with two categories. Such variables were level of higher education, gender, prior experience of self-employment, the chance of taking curricular and extra-curricular entrepreneurship course. Table 2 presents a summary description of the test results.

One of the variables considered to compare the entrepreneurial intent scale score was the level of higher education. Only two levels of higher education institutions are considered for this study-University and TVET college. The independent samples $t$ test result showed that there was a statistically significant difference in

Table 2 Summary description of independent sample $t$ test

\begin{tabular}{|c|c|c|c|c|c|c|c|c|}
\hline \multirow[b]{2}{*}{ Variables of comparison } & \multirow[b]{2}{*}{$\begin{array}{l}\text { Variable } \\
\text { categories }\end{array}$} & \multicolumn{3}{|c|}{ Group statistics } & \multicolumn{4}{|c|}{$\begin{array}{l}\text { Independent sample } t \text { test } \\
\text { for equality of means }\end{array}$} \\
\hline & & $N$ & Mean & $\begin{array}{l}\text { Std. } \\
\text { deviation }\end{array}$ & $t$ & $d f$ & $\begin{array}{l}\text { Sig. } \\
(2- \\
\text { tailed) }\end{array}$ & $\begin{array}{l}\text { Mean } \\
\text { difference }\end{array}$ \\
\hline \multirow[t]{2}{*}{ 1. Level of higher education } & $\begin{array}{l}\text { TVET } \\
\text { college }\end{array}$ & 100 & 2.7875 & .62095 & & & & \\
\hline & University & 247 & 2.5712 & .63883 & 2.880 & 345 & .004 & .21631 \\
\hline \multirow[t]{2}{*}{ 2. Gender } & Male & 237 & 2.6501 & .63963 & .709 & 345 & .479 & .05241 \\
\hline & Female & 110 & 2.5977 & .64351 & & & & \\
\hline \multirow{2}{*}{$\begin{array}{l}\text { 3. The chance of taking } \\
\text { entrepreneurship course as part of } \\
\text { higher education curriculum }\end{array}$} & Yes & 256 & 2.6413 & .61796 & & & & \\
\hline & No & 90 & 2.6102 & .70665 & .395 & 344 & .693 & .03109 \\
\hline \multirow{2}{*}{$\begin{array}{l}\text { 4. The chance of taking an extra- } \\
\text { curricular entrepreneurship course }\end{array}$} & Yes & 26 & 2.8846 & .67908 & & & & \\
\hline & No & 321 & 2.6132 & .63393 & 2.089 & 345 & .037 & .27143 \\
\hline \multirow[t]{2}{*}{ 5. Self-employment experience } & Yes & 51 & 2.8056 & .66889 & 2.087 & 345 & .038 & .20167 \\
\hline & No & 296 & 2.6039 & .63180 & & & & \\
\hline
\end{tabular}

Significance was determined with an assumption of equal variances at a $95 \%$ confidence interval for mean and $a=$ $<0.05$

Source: survey data 
Table 3 Summary description of between-groups ANOVA

\begin{tabular}{lllllll}
\hline & \multicolumn{7}{l}{ Between groups ANOVA } \\
\cline { 2 - 7 } Variables of scomparison & Number of groups & Sum of squares & $\boldsymbol{d f}$ & Mean square & $\boldsymbol{F}$ & Sig. \\
\hline 1. Colleges at Mizan-Tepi University & 7 & .706 & 6 & .118 & .283 & .945 \\
2. Departments at Mizan-Tepi University & 15 & 6.208 & 14 & .443 & 1.092 & .366 \\
3. Departments at TVET Colleges & 7 & 3.407 & 6 & .568 & 1.519 .181 \\
4. Father's occupation & 7 & 2.373 & 6 & .396 & .939 & .467 \\
5. Father's educational status & 6 & 2.128 & 5 & .426 & 1.014 .409 \\
6. Mother's occupation & 7 & 2.783 & 6 & .464 & 1.114 .354 \\
7. Mother's educational status & 6 & .505 & 5 & .101 & .240 & .945 \\
\hline
\end{tabular}

Significance was determined with an assumption of equal variances at a $95 \%$ confidence interval for mean and $a=<0.05$ Source: survey data

entrepreneurial intent scale scores for university $(M=2.57, \mathrm{SD}=0.63)$ and TVET $(M=2.78, \mathrm{SD}=0.62 ; t(345)=2.88, p=0.004)$. The magnitude ${ }^{4}$ of the differences in the means was small though (eta squared $=0.02$ ). The entrepreneurial intent scale score was greater for TVET students (2.78) as compared to university students (2.57).

The difference of entrepreneurial intent scale score was also tested between male and female sample respondents. The test showed that there was no statistically significant difference in score for male $(M=2.65, \mathrm{SD}=0.63)$ and female $(M=2.59, \mathrm{SD}=0.64 ; t$ $(345)=0.79, p=0.8$.

An independent-samples $t$ test was also conducted to compare the entrepreneurial intent score between those who took the entrepreneurship courses as part of their higher education curriculum and those who did not. The test showed that there was no statistically significant difference in scores between those who took entrepreneurship courses as part of their higher education curriculum $(M=2.64, \mathrm{SD}=0.61)$ and those who do not $(M=2.61, \mathrm{SD}=0.7 ; t(344)=0.395, p=0.693)$. However, the comparison of entrepreneurial intent scale scores based on the sample respondents' chance of taking extra-curricular entrepreneurship courses showed a statistically significant result. The result showed that there was a statistically significant difference in scores between those who took extracurricular entrepreneurship courses $(M=2.88, \mathrm{SD}=0.67)$ and those who do not $(M=2.61, \mathrm{SD}=0.63 ; t(345)=2.089, p=0.03)$. The entrepreneurial intent scale score was greater for those who took extracurricular entrepreneurship course (2.88) than those who do not (2.61). However, the magnitude of the difference was small (eta squared $=0.012$ ).

The $t$ test also showed that there was a statistically significant difference in score between those who had prior experience of self-employment $(M=2.8, \mathrm{SD}=0.66)$ and those who do not $(M=2.6, \mathrm{SD}=0.63 ; t(345)=2.087, p=.038)$. A greater score of entrepreneurial intent was observed among those who had prior experience of self-

\footnotetext{
${ }^{4}$ The magnitude of the difference was determined based on the guideline proposed by Cohen, 1988 . The formula therefore used to calculate the magnitude of the difference was:
}

$$
\text { Eta squared }=\frac{\mathrm{t}^{2}}{\mathrm{t}^{2}+\left(\mathrm{N} 1+\mathrm{N}^{2}-2\right)}
$$


employment (2.8) as compared to those who had not (2.6). But the magnitude of the difference remained small (eta squared $=0.012$ ).

\section{Between-groups ANOVA results}

Between-groups ANOVA was used to test the difference in entrepreneurial intent scale score across variables with more than two categories. Such variables were college, department, and parent's occupation and educational status. Table 3 presents a summary description of the test results.

A one-way between-group analysis of variance (ANOVA) was conducted to determine if the entrepreneurial intent score varies among university (Mizan-Tepi University) students of different colleges. Seven colleges were put under comparison. These were Social Sciences and Humanities, Business and Economics, Agriculture and Natural resource, Health Science, Engineering and Technology, Informatics, and Natural and Computational Science. The result indicated that there was no statistically significant difference $[F(6,246)=2.83, p=0.945]$ in entrepreneurial intent scores among university students of different colleges.

Entrepreneurial intent score was also compared across 17 departments of MizanTepi University. The result showed that there was no statistically significant difference $[F(14,246)=1.092, p=0.366]$ in entrepreneurial intent scale scores among university students of different departments.

One-way between-group analysis of variance (ANOVA) was also conducted to compare differences in entrepreneurial intent scale score among graduating class students of different departments in TVET colleges. The test result indicated that there was no statistically significant difference $[F(6,99)=1.51, p=0.181]$ in entrepreneurial intent scale score among TVET college graduating class students of different departments.

A One-way between-group analysis of variance (ANOVA) was also conducted to test the difference in entrepreneurial intent scale score among graduating class students across their father's occupation. The analysis result showed that there was no statistically significant difference $[F(6,338)=0.939, p=0.467]$ in entrepreneurial intent scale scores across the father's occupation.

Entrepreneurial intent scale score among graduating class students was also compared across father's level of education. The analysis showed that there was no statistically significant difference $[F(5,335)=1.014, p=0.409]$ in entrepreneurial intent scale scores across the father's educational status.

The one-way between groups ANOVA also showed no statistically significant difference in entrepreneurial intent scale score across mother's occupation $[F(6,337)=$ $1.114, p=.354]$ and educational status $[F(5,339)=.240, p=.945]$.

\section{Discussion}

To the best of our knowledge, there are no published scientific papers conducted on higher education graduates in the Kafa, Sheka, and Bench-Maji Zone. This fact has made it difficult to directly see the consistency/inconsistency of the findings of this study as compared to the findings of other researchers.

If we consider studies conducted on the subject matter in different coroners of Ethiopia though, we can find some consistencies/inconsistencies of the findings of this 
study. For instance, like this study, other studies have suggested that a greater number of higher education graduates have lower entrepreneurial intent (Adem, 2008; Atnafu, 2016; Binagde, 2014; Megibaru, 2015; Negash \& Amentie, 2013; Tesfaye, 2011).

Similar to this study, some studies have also claimed that taking extracurricular entrepreneurship courses has an impact on entrepreneurial intent (Adem, 2008; Binagde, 2014).

In line with Thuo et al. (2016), the results of this study suggest that gender does not affect entrepreneurial intent though. This claim happens to be inconsistent with the finding of several studies (Admasie et al., 2018; Asfaw, 2015; Dida Guyo, 2013; Megibaru, 2015; Tewolde et al., 2016).

Some studies support the result of this study that suggests taking entrepreneurship courses as part of the curriculum does not affect entrepreneurial intent (see Admasie et al., 2018; Dida Guyo, 2013; Tegegn et al., 2016). But plenty of other studies claim that taking entrepreneurship courses as part of the curriculum is rather significantly correlated to entrepreneurial intent (i.e., Adem, 2008; Asfaw, 2015; Atnafu, 2016; Megibaru, 2015; Thuo et al., 2016).

The result of this study that suggests parent's occupation does not have an impact on entrepreneurial intent is consistent with the findings of some studies (see Dida Guyo, 2013; Tegegn et al., 2016). But a greater number of studies claim the opposite (see Admasie et al., 2018; Asfaw, 2015; Megibaru, 2015; Tegegn et al., 2016).

Consistent with this study, Asfaw (2015) found out that a parent's level of education has no relation with students entrepreneurial intent.

Despite the convergence and divergence of the findings of this study with previous studies, readers are expected to be careful while generalizing the results of this study for two reasons. First, since this study is conducted on university and TVET students only, the findings of this study shall not be generalized to any other form of higher education institutions. Second, for this study is conducted in Kafa, Sheka, and Bench-Maji Zones, SNNPR, Ethiopia; the results of this study shall not be generalized to any university and TVET students outside of the aforementioned geographical areas.

Readers also need to be aware that the authors have passed through some challenges in the process of completing this study. Despite those challenges, the authors however have tried their best to overcome limitations and systematically ensure the overall quality of the research. For instance, one of the challenges was lack of engagement on behalf of some study participants while filling the self-administered questionnaires. In response to the problem of engagement, questionnaires assumed to be filled by unengaged respondents were eliminated during the data screening phase.

\section{Implication}

This study is expected to have six fundamental implications. One, it may inform politicians and national policy-makers that the vast majority of higher education graduates in the study area are most likely going to be job-seekers in a country where there are no adequate employment opportunities. Two, it may inform the ministry of science and higher education that curricular entrepreneurship training has not been effective in building entrepreneurial intent of their students while extra-curricular entrepreneurship training does. This would create a general condition for the ministry to assess and modify its approach towards entrepreneurship 
education. Three, some of the findings of this study that violated commonsense wisdom may inspire other researchers to explore more on the subject matter. Four, it may present empirical evidence for the significant association of demographic variables and other background characteristics with entrepreneurial intention. This would be evidence for the demographic models and theories of entrepreneurial intent are yet as important as a personality trait, intention, and/or attitudinal models. Five, it may inform managers of business enterprises about how extra-curricular entrepreneurship training could shape the entrepreneurial intention of their future employees. In this instance, it is worth noting that the prospective graduates who participated in this research were on their way to join the workforce. Six, the study may also inform those who wish to engage in entrepreneurial activities about how much taking extracurricular entrepreneurship training could be useful for their future entrepreneurial career.

\section{Conclusion}

This study claims that around half of higher educational institution graduates in the study area are less likely to engage in entrepreneurial activities soon after graduation. It also claims that only less than a quarter of higher educational institution graduates in the study area tend to engage in entrepreneurial activities soon after their graduation.

The results of this study suggest that level of higher education, prior experience of self-employment, and the chance of taking extracurricular entrepreneurship courses are the only distal variables that may explain the difference in entrepreneurial intent among the study population. For instance, as compared to university graduates, TVET college graduates are more likely to engage in entrepreneurial activities soon after graduation. It also seems that as compared to higher educational institution graduates who did not take extracurricular entrepreneurship course training, those who did take are more likely to engage in entrepreneurial activities soon after graduation. This study also suggests that those who have prior experience of self-employment are more likely to manifest an entrepreneurial behavior.

The results of this study however suggest that; gender, the chance of taking entrepreneurship courses as part of the curriculum, college, department, parent's occupation, and level of education are variables that may not explain the difference in entrepreneurial intent among then study population.

\section{Supplementary Information}

The online version contains supplementary material available at https://doi.org/10.1186/s13731-020-00137-1.

Additional file 1. Entrepreneurial Intent Measurement Scale (Adapted from Edmund R. Thompson (2009).

Additional file 2. Reliability Test Result of Entrepreneurial Intent Measurement Scale.

Additional file 3. Questions related to Demographic and other Distal Variables.

\section{Abbreviations}

ANOVA: Analysis of variance; MoE: Ministry of Education; SNNPR: Southern Nation Nationalities Peoples' Region; TVET: Technical and Vocational Education and Training; USAID: United States Agency for International Development; TBA: Theory of planned behavior 


\section{Authors' contributions}

Both authors have equally contributed to this study from proposal development to manuscript writing stages. The author(s) read and approved the final manuscript.

\section{Funding}

The source of funds for this study was Mizan-Tepi University, Ethiopia. Other than covering the entire cost related to this study, the funding body had no role in the study design, data collection, analysis, and interpretation, or write-up.

\section{Availability of data and materials}

The datasets analyzed during the current study are not publicly available due they are part of an ongoing research project but are available from the corresponding author on reasonable request.

\section{Competing interests}

To the best of our knowledge, no competing financial and non-financial interests are present concerning the manuscript.

\section{Author details}

${ }^{1}$ Mizan-Tepi University, Mizan-Aman City, Ethiopia. ${ }^{2}$ Debre Berhan University, Debre Berhan City, Ethiopia.

\section{Received: 21 January 2020 Accepted: 20 October 2020}

Published online: 13 November 2020

\section{References}

Adem, E. Y. (2008). The Effect of Entrepreneurship Training in Tvet Programs As a Source of Motivation for Entrepreneurship. (Master's Thesis. Ethiopia: Addis Ababa University.

Admasie, M. G., Kassahun, T. A., \& Wodajo, M. G. (2018). A Study on Students' Entrepreneurial Intention: The Case of Wollega University, Ethiopia. Journal of Exclusive Management Science - April 2018 - Vol 7 Issue 04 - ISSN 2277-5684, 15(2), 20172019. https://doi.org/10.22201/fq.18708404e.2004.3.66178.

Ajzen, I. (1987). Attitudes, traits, and actions: Dispositional prediction of behavior in personality and social psychology. Advances in Experimental Social Psychology, 20, 1-63 Elsevier.

Ajzen, I. (1991). The theory of planned behavior. Organizational Behavior and Human Decision Processes, 50(2), 179-211. https://doi.org/10.1016/0749-5978(91)90020-T.

Alemu, K. S., \& Ashagre, K. T. (2016). Determinants of Entrepreneurial Intent Among University Students: a Case of Ambo University. Journal of Asian and African Social Science and Humanities, 1(3), 117-131.

Alsos, G. A., Carter, S., \& Ljunggren, E. (2011). The handbook of research on entrepreneurship in agriculture and rural development. Edward Elgar Publishing.

Altinay, L., Madanoglu, M., Daniele, R., \& Lashley, C. (2012). The Influence of Family Tradition and Psychological Traits on Entrepreneurial Intention. International Journal of Hospitality Management, 31(2), 489-499. https://doi.org/10.1016/j.jhm. 2011.07.007.

Asfaw, A. (2015). Entrepreneurial Intention of Undergraduate Students: Impacts of Attitudes and Role Model. (Master's Thesis. Ethiopia: Addis Ababa University.

Astatike, G. H. (2003). The Incidence of Youth Unemployment in Urban Ethiopia. In 2nd international EAF Conference, Organized by Western Michigan University and Addis Ababa University from Jul 11-13 Retrieved from https:// westminsterresearch.westminster.ac.uk/download/dda91dac77393a97863c30a47a8c38aec1844342c173b005b64aa98d11 efc982/194072/Haile_2003_final.pdf.

Atnafu, A. M. (2016). Analysis of Determinants of Students Self Employment Intention in Newly Established Universities of Ethiopia. International Journal of Scientific and Research Publications, 6(4), 25-41 Retrieved from www.jsrp.org.

Audretsch, D. B., Carree, M. A., \& Thurik, A. R. (2001). Does entrepreneurship reduce unemployment? Tinbergen Institute discussion paper.

Basu, A., \& Virick, M. (2007). Assessing Entrepreneurial Intentions Amongst Students : A Comparative Study Peer-Reviewed Papers. In VentureWell. Proceedings of Open, the Annual Conference, (vol. 2000, pp. 79-86) Retrieved from https:/www. researchgate.net/profile/Anuradha_Basu/publication/255583956_Assessing_Entrepreneurial_Intentions_Amongst_ Students_A_Comparative_Study/links/5411ffb10cf2fa878ad394f0.pdf.

Bergmann, H., \& Sternberg, R. (2007). The changing face of entrepreneurship in Germany. Small Business Economics, 28(2-3), 205-221. https://doi.org/10.1007/s11187-006-9016-z.

Binagde, T. N. (2014). Factors affecting graduates of technical and vocational education and training on self-employment status: the case of Burayu Technical \& Vocational Education \& Training. (Master's Thesis, Addis Ababa University, Ethiopia).

Bird, B. (1988). Implementing entrepreneurial ideas: the case for intention. Academy of Management Review, 13(3), 442-453.

Bosma, N. S., \& Levie, J. (2010). Global Entrepreneurship Monitor 2009 Executive Report.

Broussar, N. H., \& Tekleselassie, T. G. (2012). Youth unemployment, Ethiopia country study. In International Growth Centre (IGC) Working Paper (No. 0592). Retrieved from http://prime-ethiopia.org/wp-content/uploads/2015/03/Youth Unemployment-Ethiopia Country Study.pdf

Castellano, S., Maalaoui, A., Safraou, I., \& Reymond, E. (2014). Linking intuition and entrepreneurial intention: a comparative study among French and US student entrepreneurs. International Journal of Entrepreneurship and Innovation Management, 18(1), 23. https://doi.org/10.1504/ijeim.2014.062787.

Chakrabartty, S. N. (2013). Best split-half and maximum reliability. IOSR Journal of Research \& Method in Education, 3(1), 1-8.

Chaudhary, R. (2017). Demographic factors, personality, and entrepreneurial inclination. Education+ Training.

Choo, S., \& Wong, M. (2006). Entrepreneurial intention: triggers and barriers to new venture creations in Singapore. Singapore Management Review, 28(2), 47-64.

Cortina, J. M. (1993). What is coefficient alpha? An examination of theory and applications. Journal of Applied Psychology $78(1), 98$. 
Daim, T., Dabic, M., \& Bayraktaroglu, E. (2016). Students' entrepreneurial behavior: international and gender differences. Journal of Innovation and Entrepreneurship, 5(1), 19.

De Pillis, E., \& Reardon, K. K. (2007). The influence of personality traits and persuasive messages on entrepreneurial intention: a cross-cultural comparison. Career Development International, 12(4), 382-396. https://doi.org/10.1108/ 13620430710756762.

De, R. M. (2010). Ways to come, ways to leave: gender, mobility, and illegality among ethiopian domestic workers in Yemen. Gender and Society, 24(2), 237-260. https://doi.org/10.1177/0891243209360358.

Delivery Associates Ltd. (2017). Applying "deliverology" in priority areas to drive for results. higher education workshop 31 July 11 August 2017, (August). Adama: Delivery Associates Ltd.

Denu, B., Tekeste, A., \& Deijl, V. D. H. (2005). Characteristics and determinants of youth unemployment in Ethiopia. Ethiopian Journal of Development Research, 33. https://doi.org/10.4314/ejdr.v33i1.68614.

Devonish, D., Alleyne, P., Charles-Soverall, W., Marshall, A. Y., \& Pounder, P. (2010). Explaining entrepreneurial intentions in the Caribbean. International Journal of Entrepreneurial Behaviour and Research, 16(2), 149-171. https://doi.org/10.1108/ 13552551011027020.

Díaz-Casero, J. C., Ferreira, J. J. M., Mogollón, R. H., \& Raposo, M. L. B. (2012). Influence of institutional environment on entrepreneurial intention: a comparative study of two Tountries university students. International Entrepreneurship and Management Journal, 8(1), 55-74. https://doi.org/10.1007/s11365-009-0134-3.

Dida Guyo, G. (2013). Entrepreneurial intention and its determinants: evidence from university students in Addis Ababa ((Master's Thesis, Addis Ababa University, Ethiopia)). Retrieved from http://etd.aau.edu.et/bitstream/123456789/5575/1/ Golo Dida.pdf

Es, M., \& Urbano, D. (2005). University students' attitudes towards entrepreneurship: a two countries comparison. International Entrepreneurship and Management Journal, 12, 165-182.

Fairlie, R. W., \& Robb, A. (2007). Families, human capital, and small business: evidence from the characteristics of business owners survey. ILR Review, 60(2), 225-245.

Fanchu, F. (2017). Exploring the factors pushing criminal suspects to commit crime: the case of Soddotown in Wolaita Zone, Southern Ethiopia ((Master's Thesis, Addis Ababa University, Ethiopia)). Retrieved from http://etd.aau.edu.et/ handle/123456789/1696

Fatoki, O. (2014). Parental and gender effects on the entrepreneurial intention of university students in South Africa. Mediterranean Journal of Social Sciences, 5(7), 157-162. https://doi.org/10.5901/mjss.2014.v5n7p157.

Fayolle, A., Gailly, B., \& Lassas-Clerc, N. (2006). Effect and counter-effect of entrepreneurship education and social context on student's intentions. Estudios de Economía Aplicada, 24(2), 509-523 Retrieved from http://dialnet.unirioja.es/descarga/ articulo/2103744.pdf.

Fila, D. T., Mansingh, P. J., \& Legesse, W. (2016). Consequences of youth unemployment: the case of Ambotown, Oromia, Ethiopia. IMPACT: International Journal of Research in Applied, Natural, and Social Sciences (IMPACT: IJRANSS), 4(10), 69-71 Retrieved from https://papers.ssrn.com/sol3/papers.cfm?abstract_id=3115958.

Gartner, W. B., Shaver, K. G., Gatewood, E., \& Katz, J. A. (1994). Finding the entrepreneur in entrepreneurship. Los Angeles: SAGE Publications Sage CA.

Gelard, P. (2012). Impact of some contextual ffactors on entrepreneurial intention of university students. African Journal of Business Management, 5(26), 10707-10717. https://doi.org/10.5897/ajbm10.891.

International Labour Organization. (2017). Global Employment Trends for Youth 2017 : Paths to a better working future. Retrieved from http://www.voced.edu.au/content/ngv:78227

Israel, G. D. (1992). Determining Sample Size, (pp. 1-5). Florida: Institute of Food and Agricultural Sciences, University of Florida.

Jenkins, M., \& Johnson, G. (1997). Entrepreneurial intentions and outcomes: a comparative causal mapping study. Journal of Management Studies, 34(6), 895-920. https://doi.org/10.1111/1467-6486.00077.

Kassaye, M., Sherief, H. T., Fissehaye, G., \& Teklu, T. (1999). Knowledge of "drug" use and associated factors as perceived by health professionals, farmers, the youth and law enforcement agencies in Ethiopia. Ethiopian Journal of Health Development, 13(2), 141-150 Retrieved from http://ejhd.uib.no/ejhd-v13/ejhd-v13-n2-141.htm.

Kautonen, T., Tornikoski, E. T., \& Kibler, E. (2011). Entrepreneurial intentions in the third age: the impact of perceived age norms. Small Business Economics, 37(2), 219-234. https://doi.org/10.1007/s11187-009-9238-y.

Kimberlin, C. L., \& Winterstein, A. G. (2008). Validity and reliability of measurement instruments used in research. American Journal of Health-System Pharmacy, 65(23), 2276-2284.

Krueger Jr., N. F., \& Day, M. (2010). Looking forward, looking backward: from entrepreneurial cognition to neuroentrepreneurship. In Handbook of entrepreneurship research, (pp. 321-357). Springer.

Last, J. M., Harris, S. S., Thuriaux, M. C., \& Spasoff, R. A. (2001). A dictionary of epidemiology. International Epidemiological Association, Inc

Leta, S., \& Waktole, D. (2017). Determinants of entrepreneurial intention of university graduates in Oromia Regional. International Journal of Research in Social Sciences, 7(5), 220-246 Retrieved from http://www.jimra.us.

Liñán, F., \& Chen, Y.-W. (2006). Testing the entrepreneurial intention model on a two-country sample. Departament d'Economia de l'Empresa. https://doi.org/10.1016/j.transproceed.2018.02.024.

Lüthje, C., \& Franke, N. (2003). The "making" of an entrepreneur: testing a model of entrepreneurial intent among engineering students at MIT. R and D Management, 33(2), 135-147. https://doi.org/10.1111/1467-9310.00288.

McElwee, G., \& Al-Riyami, R. (2003). Women entrepreneurs in Oman: some barriers to success. Career Development International.

McMillan, J. H., \& Schumacher, S. (2006). Research in education : evidence-based inquiry. Retrieved from https://www.google. $\mathrm{com} /$ search?ei=y8ccXc6UPJLkgweAo7DwDQ\&q=Research+in+Education\%3A+Evidence+Based+Inquiry\%2C+6th+ Edition+\&oq=Research+in+Education\%3A+Evidence+Based+Inquiry\%2C+6th+Edition+\&gs_l=psy-ab.3.35i39.108643.1 09813.110207...0.0.0.6.621.621.5-1...

Meek, W. R., Pacheco, D. F., \& York, J. G. (2010). The impact of social norms on entrepreneurial action: evidence from the environmental entrepreneurship context. Journal of Business Venturing, 25(5), 493-509. https:/doi.org/10.1016/j.jbusvent.2009.09.007.

Megibaru, S. (2015). Socio-demographic determinants for entrepreneurial intention of university students: the case of university of Gondar graduating students. Ethiopian Journal of Business and Economics (The), 4(1), 50. https://doi.org/10. 4314/ejbe.v4i1.2. 
Ministry of Education MoE. (2007). National technique and vocational training strategy. Retrieved from https://chilot.me/ nationa-policies-and-strategies/?download=5907

Mohajan, H. K. (2017). Two criteria for good measurements in research: validity and reliability. Annals of Spiru Haret University. Economic Series, 17(4), 59-82

Mukorera, S., \& Mahadea, D. (2014). Linking entrepreneurial activity to economic meltdown in Zimbabwe. Mediterranean Journal of Social Sciences, 5(3), 42-50. https://doi.org/10.5901/mjss.2014.v5n3p42.

Mulugeta Atnafu, A. (2016). Analysis of determinants of students' self-employmentment intention in newly established Universities of Ethiopia. International Journal of Scientific and Research Publications, 6(4), 25-41 Retrieved from www.ijsrp.org.

Negash, E., \& Amentie, C. (2013). An investigation of higher education student's entrepreneurial intention in Ethiopian universities: technology and business fields in focus. Basic Research Journal of Business Management and Accounts, 2(2), 30-35 Retrieved from https://opendocs.ids.ac.uk/opendocs/handle/123456789/9723.

Nguyen, C. (2018). Demographic factors, family background, and prior self-employment on entrepreneurial intention Vietnamese business students are different: why? Journal of Global Entrepreneurship Research, 8(1). https://doi.org/10.1186/ s40497-018-0097-3.

Nunnally, J. C., \& Bernstein, I. H. (1978). Psychometric Theory McGraw-Hill New York. In The role of university in the development of entrepreneurial vocations: a Spanish study.

Ozgul, U., \& Kunday, O. (2015). Conceptual development of academic entrepreneurial intentions scale. Procedia - Social and Behavioral Sciences, 195, 881-887. https://doi.org/10.1016/j.sbspro.2015.06.367.

Pihie, Z. A. L., Bagheri, A., \& Sani, Z. H. A. (2009). Examining the entrepreneurial attitudes of malaysian secondary school students. International Journal of Learning, 16(10).

Quan, X. (2012). Prior experience, social network, and levels of entrepreneurial intentions. Management Research Review.

Schlaegel, C., \& Koenig, M. (2014). Determinants of entrepreneurial intent: a meta-analytic test and integration of competing models. Entrepreneurship: Theory and Practice, 38(2), 291-332. https://doi.org/10.1111/etap.12087.

Streiner, D. L., Norman, G. R., \& Cairney, J. (2015). Health measurement scales: a practical guide to their development and use. USA: Oxford University Press.

Tegegn, T., Paulos, M., \& Desalegn, Y. (2016). Determinants of entrepreneurial intention among prospective graduates of higher institutions case of Wolaita Sodo University. Journal of Education and Practice, 7(16), 2222-1735 Retrieved from http://www.emeraldinsight.com/doi/pdfplus/10.1108/03090590910939049.

Ternandez, B. (2011). Household help? Ethiopian women domestic workers' labor migration to the Gulf countries. Asian and Pacific Migration Journal, 20(3-4), 433-457 Retrieved from https://journals.sagepub.com/doi/abs/10.1177/011719681102 000309.

Tesfaye, F. (2011). Factors affecting self- employment of technical and vocational education and training graduates: the case of St. Mary'S University College ((Master's Thesis, Addis Ababa University, Ethiopia)). Retrieved from http://etd.aau.edu.et/ handle/123456789/15538

Tewolde, A., Feleke, C., Mamo, K., Hayat, F., \& Siyom, S. (2016). Challenges and prospects of entrepreneurship development and job creation for youth unemployed: evidence from Addis Ababa and Dire Dawa city Administrations, Ethiopia. Retrieved from https://www.pep-net.org/sites/pep-net.org/files/CBMS/PEP_Mtng/13th/Papers/Abel_Tewolde_Ethiopia_.pdf

Thatcher, R. W. (2010). Validity and reliability of quantitative electroencephalography. Journal of Neurotherapy, 14(2), $122-152$.

The Federal Democratic Republic of Ethiopia. A Proclamation to Ammend the Higher Education Proclamation No.650/2009. Pub. L. No. 861/2014 (2014).

Thompson, E. R. (2009). Individual entrepreneurial intent: construct clarification and development of an internationally reliable metric. Entrepreneurship Theory and Practice, 33(3), 669-694. https://doi.org/10.1111/j.1540-6520.2009.00321.x.

Thuo, M., Abo, T., \& Toma, S. (2016). Entrepreneurial intentions of university students: Insights for entrepreneurial education in Ethiopia. European Journal of Business and Management, 8(22), 25-35 Retrieved from https://pdfs.semanticscholar.org/ 0490/eb1675dabe0e34f4bbe40599a842bea41de2.pdf.

Thurik, R., \& Wennekers, S. (2004). Entrepreneurship, small business and economic growth. Journal of Small Business and Enterprise Development, 11(1), 140-149. https://doi.org/10.1108/14626000410519173.

Tkachev, A., \& Kolvereid, L. (1999). Self-employment intentions among Russian students. Entrepreneurship \& Regional Development, 11(3), 269-280.

USAID (2017). Developing Ethiopia'S Youth. (July 2017), (pp. 1-2) Retrieved from WWW.USAID.GOV/ETHIOPIA.

Valliere, D. (2014). Purifying entrepreneurial intent: proposition of a new scale. Journal of Small Business and Entrepreneurship, 27(5), 451-470. https://doi.org/10.1080/08276331.2015.1094225.

Valliere, D. (2015). An effectuation measure of entrepreneurial intent. Procedia - Social and Behavioral Sciences, 169(August 2014), 131-142. https://doi.org/10.1016/j.sbspro.2015.01.294.

Wang, Y. Y., Lin, H. C., \& Jiang, C. L. (2013). An empirical study on the relationship between background heterogeneity, entrepreneurial attitude, and entrepreneurial intention - based on questionnaire survey to postgraduates in China. In International Conference on Management Science and Engineering - Annual Conference Proceedings, (05021438), (pp. 934943). https://doi.org/10.1109/ICMSE.2013.6586390.

Wubie, H. (2012). Youth Unemployment in Ethiopia : An overview, (p. 3) Retrieved from http://englishbulletin.adapt.it/docs/ hiruy_2012.pdf.

\section{Publisher's Note}

Springer Nature remains neutral with regard to jurisdictional claims in published maps and institutional affiliations. 